\title{
Effect of Thermal-Cold Cycle on Microstructure and Hardness of a W-Cr-Mn-Mo-V Ferro-based Hardfacing
}

\section{Layer}

\author{
ZHANG Zuowei $^{1}$, QI Mai Shun ${ }^{2}$ and ZHAO Jun ${ }^{3}$ \\ 1. Logistics Groups Company, Yanshan University, Qinhuangdao 066004, China \\ 2. School of Continuing Education, Yan Shan University, Qinhuangdao 066004, China \\ 3. Department of Materials and Engineering, North China Institute of Aerospace Engineering, Langfang 065000, China
}

\begin{abstract}
The effect of heating temperature and thermal-cold recycle times on microstructure and hardness of a W-Cr-Mn-Mo-V Ferro-based hardfacing layer was studied. The results show the surfacing layer has good high-temperature stability and ability to resist quench heat and heat softening. After thermal-cold recycle at $560{ }^{\circ} \mathrm{C} \Leftrightarrow 18^{\circ} \mathrm{C}$ for 120 times, the hardness of the hardfacing layer is HRC 57.5 , its microstructure is mainly tempered martensite and a small amount of retained austenite, when thermal-cold recycled at $680{ }^{\circ} \mathrm{C} \Leftrightarrow 18^{\circ} \mathrm{C}$ for 120 times, the hardness of the hardfacing layer is HRC 44.5 , martensite in the hardfacing layer has almost decomposed.
\end{abstract}

Key words: W-Cr-Mn-Mo-V Ferro-based hardfacing layer, thermal-cold cycles, microstructure, hardness.

\section{Introduction}

Hot-rollers and scissors always afford the heat-stress effect of thermal-cold recycle when they are working in the field of metallurgy, mining and mechanism industries. This effect results in the early surface softening and the thermal-cold fatigue damage of the workpiece $[1,2]$. At present, thermal-cold fatigue damage wearing and the tearing has become one of the main reasons of hot-rollers and scissors failure. Consequently, improving the using performance of workpiece under bad working condition is of very important economic benefit. Hardfacing is a simple and economic method to repair and improve surface performance of workpiece and has been widely used, but this technology has common problem: if the hardfacing layer contains more excessive alloy elements, not only the cost becomes higher but also does the hardfacing layer

Corresponding author: ZHANG Zuowei, senior engineer, research field: metallic materials. show an obvious tendency to crack in the course of hardfacing. On the contrary, if the hardfacing layer has less alloy elements, the cost becomes lower, but the tendency to crack lessens, and its function, especially the hardness cannot satisfy the requirements of the materials. Therefore, the properties of hardfacing layer improved have attracted considerable attention [3-6]. Hardfacing layer not only is possessed of higher hardness but also softening resistance of thermal-cold recycle to avoid wearing and the tearing of workpiece. Now, considerable scientific efforts have been direct to the composition, microstructure and properties of the hardfacing layer [7-10], but few reports show the effect of thermal-cold recycle on structure and properties of the hardfacing layer. In this article, we introduce a new W-Cr-Mn-Mo-V Ferro-based hardfacing welding rod, the hardness of this hardfacing layer under different thermal-cold recycle conditions is tested. Experimental result has instructional meaning for the use of this hardfacing welding rod. 


\section{Experiments}

W-Cr-Mn-Mo-V Ferro-based hardfacing welding rod is prepared by using H08A welding core with a diameter of $4 \mathrm{~mm}$ and coating which is made of marble, fluorite, titanium whiting powder adding different alloy power including $\mathrm{W}, \mathrm{Mo}, \mathrm{Cr}, \mathrm{Mn}, \mathrm{V}$. The $45 \#$ steel is overlayed with W-Cr-Mn-Mo-V Fe-base electrode by ZX5-250 direct current electric welding machine. The thickness of hardfacing layer is 3-4 mm, keeping air cooling after welding, the size of hardfacing samples is $30 \mathrm{~mm} \times 30 \mathrm{~mm} \times 10 \mathrm{~mm}$. Afterward, the hardfacing specimens is separately heated to $500{ }^{\circ} \mathrm{C}, 560{ }^{\circ} \mathrm{C}, 620{ }^{\circ} \mathrm{C}, 680{ }^{\circ} \mathrm{C}$ in a SX-4-10 type resistance furnace and keeps temperature for 5 minutes, then rapidly quenched in $18{ }^{\circ} \mathrm{C}$ water, and then do the cool and heat cycle experiment. The hardness of the hardfacing layer surface and micro-zone are measured by HR-150A rock well hardness and HVS-1000 microscope hardness sclerometer. The microstructure and the composition of micro-zone of hardfacing layer were observed and analyzed by NEOPHOT21 optical microscope, KYKY-2800 scanning electron microscope with EDS, H-800 transmission electron microscope, and D/MAX-rB X-ray diffraction (with graphite monochromator, $\mathrm{K}_{\mathrm{a}}$ radiation).

\section{Results and Discussion}

\subsection{Microstructure of Hardfacing Layer}

Fig. 1 shows the microstructures of the surfacing layer under different states. It can be seen that the microstructure of the hardfacing layer before tempering is composed of irregular white zone and black matrix, the white zone disappeared after thermal-cold recycle, and the white zone disappeared obviously as the temperature increasing, The majority of irregular white zone and black matrix are iron element from test result of elements and hardness of the white zone and black matrix (Table 1) and the white zone contains much more alloy (W, Cr, Mo) than that in the black area. XRD (Fig. 2) analysis indicates that martensite and residual austenite are the main structure. So we conclude that the white zone is high alloy martensite and the black matrix is mainly low alloy martenstic and residual Austenite. W-Cr-Mn-Mo-V Ferro-based hardfacing layer after thermal-cold recycled at $560{ }^{\circ} \mathrm{C} \Leftrightarrow 18{ }^{\circ} \mathrm{C}$ for 120 times, the microstructure of the hardfacing layer is mainly tempered martensite and a few residual austenite. While thermal-cold recycled at $680{ }^{\circ} \mathrm{C} \Leftrightarrow$ $18{ }^{\circ} \mathrm{C}$ for 120 times, and residual Austenite has disappeared in the hardfacing layer, the alloy carbide including $\mathrm{Mo}_{2} \mathrm{C}, \mathrm{Fe}_{3} \mathrm{~W}_{3} \mathrm{C}, \mathrm{Cr}_{23} \mathrm{C}_{6}$ is deposited. As shown in the TEM patterns (Fig. 3), martensite in the hardfacing layer microstructure after $560^{\circ} \mathrm{C} \Leftrightarrow 18^{\circ} \mathrm{C}$ for 120 times, and after $680{ }^{\circ} \mathrm{C} \Leftrightarrow 18^{\circ} \mathrm{C}$ for 120 times, martensite has almost decomposed.

\subsection{Hardness of the Hardfacing Layers}

Fig. 4 shows that the hardness of W-Cr-Mn-Mo-V Ferro-based hardfacing layers tempered at different

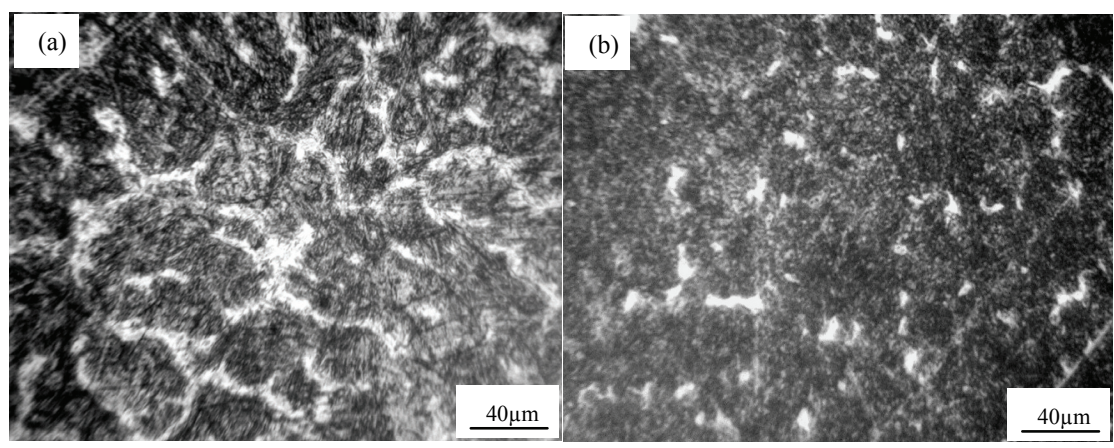

(a) As welded (b) $560{ }^{\circ} \mathrm{C} \Leftrightarrow 18^{\circ} \mathrm{C}$ for 120 times

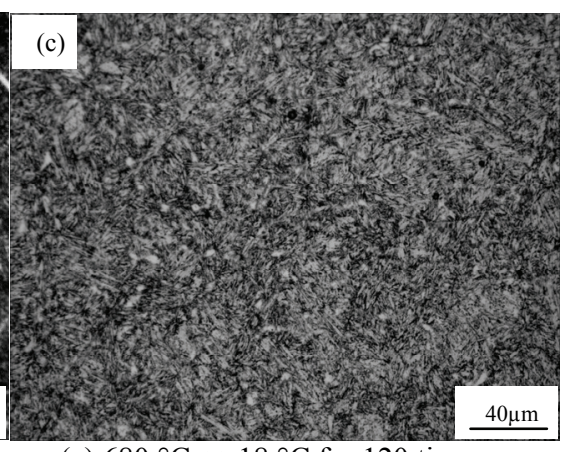

(c) $680^{\circ} \mathrm{C} \Leftrightarrow 18^{\circ} \mathrm{C}$ for 120 times

Fig. 1 Microstructure of the hardfacing layer. 
Effect of Thermal-Cold Cycle on Microstructure and Hardness of a

W-Cr-Mn-Mo-V Ferro-based Hardfacing Layer

Table 1 The micro-zone composition and micro-hardness measured value.

\begin{tabular}{lllllll}
\hline Area & $\mathrm{Fe}$ & $\mathrm{W}$ & $\mathrm{Cr}$ & Mo & Others & $\mathrm{HV}_{0.2}$ \\
\hline White & 87.52 & 8.04 & 2.46 & 1.34 & 0.64 & 975 \\
Black & 94.07 & 3.15 & 1.63 & 0.62 & 0.53 & 681 \\
\hline
\end{tabular}

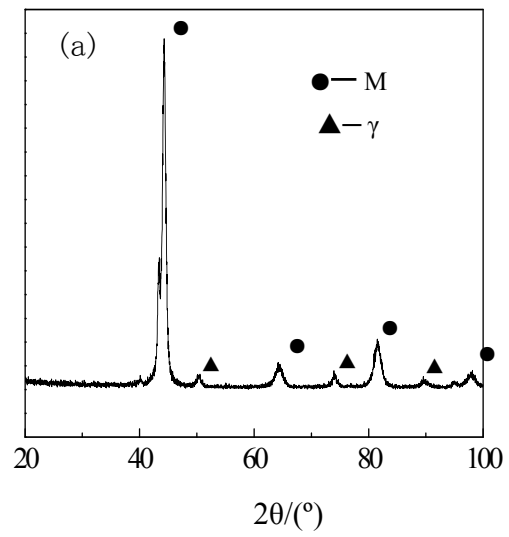

(a) As welded

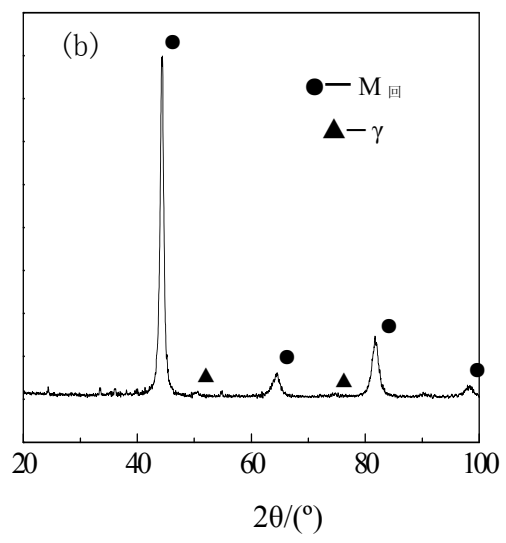

(b) $560{ }^{\circ} \mathrm{C} \Leftrightarrow 18^{\circ} \mathrm{C}$ for 120 times

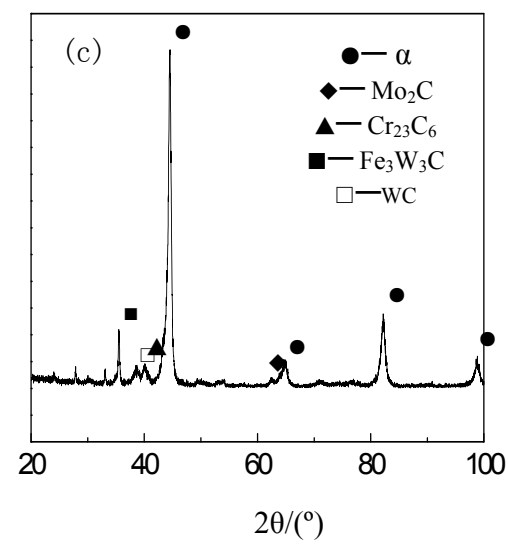

(c) $680{ }^{\circ} \mathrm{C} \Leftrightarrow 18^{\circ} \mathrm{C}$ for 120 times

Fig. 2 XRD patterns of the hardfacing layer.

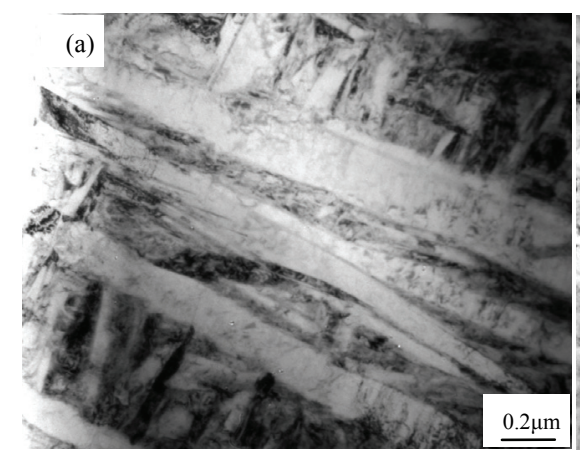

(a) As welded

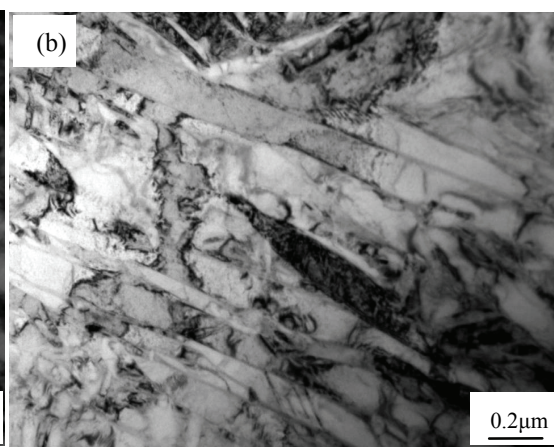

(b) $560^{\circ} \mathrm{C} \Leftrightarrow 18^{\circ} \mathrm{C}$ for 120 times

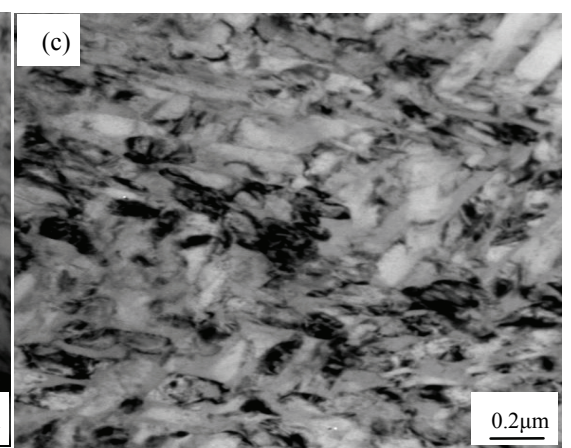

(c) $680{ }^{\circ} \mathrm{C} \Leftrightarrow 18^{\circ} \mathrm{C}$ for 120 times

Fig. 3 TEM images of the hardfacing layers.

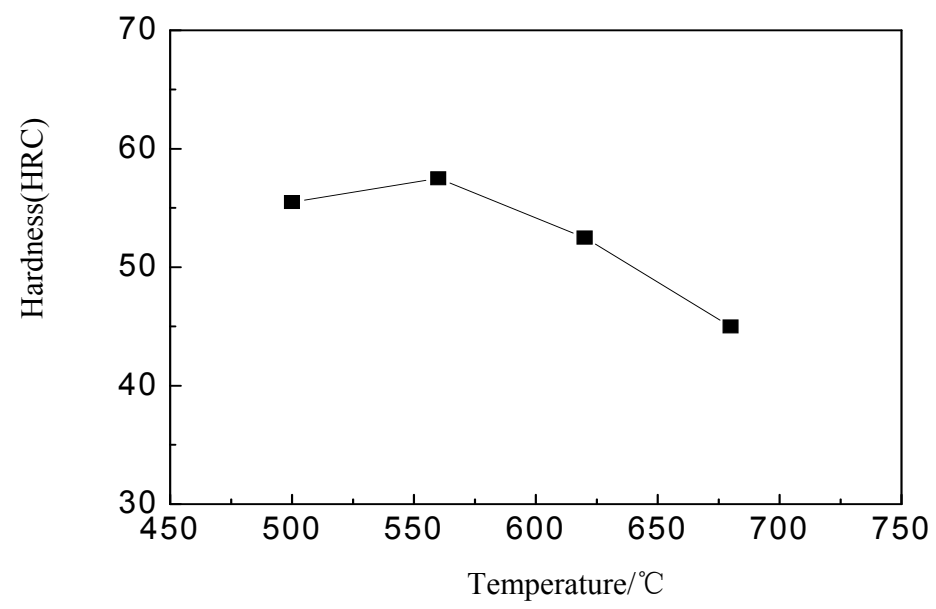

Fig. 4 Effect of heating temperature on the hardness of hardfacing layer after recycle for 100 times. 
temperatures after thermal-cold recycle for 100 times. It can be seen that the hardness of hardfacing layer increases as the temperature increasing, and HRC 57.5 is the peak value of hardness when tempered at $560{ }^{\circ} \mathrm{C}$. Afterward, the hardness of hardfacing layer decreases as the temperature increasing. Fig. 5 shows the hardness value of the hardfacing layer after thermal-cold recycle at different temperatures and thermal-cold recycle times. It can be seen that the hardness of hardfacing layer is around HRC 55, changes slowly after thermal-cold recycle at $500{ }^{\circ} \mathrm{C}$ $\Leftrightarrow 18^{\circ} \mathrm{C}$. The hardness of hardfacing layer increases as thermal-cold recycle times increasing by thermal-cold recycle at $560{ }^{\circ} \mathrm{C} \Leftrightarrow 18{ }^{\circ} \mathrm{C}$, The hardness of hardfacing layer keeps unchanged and is about HRC 57.5 after recycle for 80 times. The hardness of hardfacing layer decreases as thermal-cold recycle times increasing by thermal-cold recycle at $620^{\circ} \mathrm{C} \Leftrightarrow 18^{\circ} \mathrm{C}$ and $680^{\circ} \mathrm{C} \Leftrightarrow 18^{\circ} \mathrm{C}$, the hardness of hardfacing layer decreases faster at $680{ }^{\circ} \mathrm{C} \Leftrightarrow 18{ }^{\circ} \mathrm{C}$. The results show the hardness of hardfacing layer descends from HRC 55 to HRC 44.5 by thermal-cold recycle at $680^{\circ} \mathrm{C} \Leftrightarrow 18{ }^{\circ} \mathrm{C}$ for 120 times.

\subsection{Discussion}

From above, we can conclude that a
W-Cr-Mn-Mo-V Ferro-based hardfacing layer has higher hardness and stability microstructure after thermal-cold recycle. As a result, the hardfacing layer is possessed of better high-temperature microstructure stability and softening resistance of thermal-cold recycle, which is due to a large amount of alloy elements (W, Mo, Cr) contained in hardfacing layer. They stop carbon atoms from separating from martensite and delay the decomposition of martensite, which effectively increase the decomposition temperature of martensite, even heated to about $560{ }^{\circ} \mathrm{C}$, the martensite still has good stability, and even stop the decomposition of residual Austenite, recovery and recrystallization of $\alpha$-phase $[11,12]$. It can be seen that the hardness of hardfacing layer increases by thermal-cold recycle at $560^{\circ} \mathrm{C} \Leftrightarrow 18^{\circ} \mathrm{C}$ for 80 times. When the hardfacing layer was thermal-cold recycled at $560{ }^{\circ} \mathrm{C} \Leftrightarrow 18{ }^{\circ} \mathrm{C}$, on one hand, fine alloyed carbide is deposited, which forms obviously precipitating induration action. On the other hand, the alloyed carbide deposited in residual austenite and the concentration of carbide and alloy elements reduce, therefore, Ms point of residual austenite rises [13]. The residual austenite is changed into martensite, which produces the effect of secondary hardening. The action of two aspects results

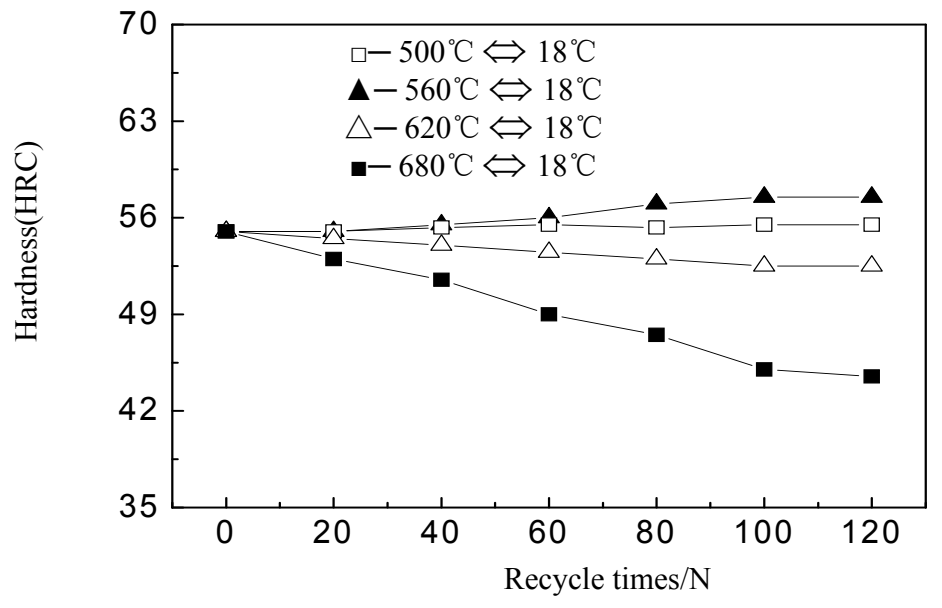

Fig. 5 Effect of thermal-cold recycle times on the hardness of the hardfacing layer. 
in the increase of the hardness of hardfacing layer. XRD (Fig. 3) analysis indicates that after the hardfacing layer thermal-cold recycled at $560{ }^{\circ} \mathrm{C} \Leftrightarrow$ $18{ }^{\circ} \mathrm{C}$, alloyed carbide is not deposited, this may be related to precision of XRD. When thermal-cold recycle temperature is above $560{ }^{\circ} \mathrm{C}$, alloyed carbide will grow up and dispersion degree of carbide will reduce. At the same time, martensite has decomposed in the hardfacing layer and $\alpha$-phase has happened restoration and recrystallization, which results in the decrease of the hardness.

\section{Conclusions}

(1) The microstructure of a W-Cr-Mn-Mo-V Ferro-based hardfacing layer is mainly martensite and residual austenite. The hardfacing layer is possessed of better high-temperature microstructure stability and softening resistance of thermal-cold recycle. .

(2) It can be seen that the hardness of hardfacing layer changes slowly after thermal-cold recycle at $500{ }^{\circ} \mathrm{C} \Leftrightarrow 18{ }^{\circ} \mathrm{C}$. The hardness of hardfacing layer increases to HRC 57.5 by thermal-cold recycle at $560{ }^{\circ} \mathrm{C} \Leftrightarrow 18{ }^{\circ} \mathrm{C}$ for 80 times, the microstructure of hardfacing layer is mainly tempered martensite and a few residual austenite. The hardness of hardfacing layer decreases as thermal-cold recycle temperature increasing, the hardness of hardfacing layer is HRC 44.5 when thermal-cold recycled at $680^{\circ} \mathrm{C} \Leftrightarrow 18^{\circ} \mathrm{C}$ for 120 times, martensite in the hardfacing layer has almost decomposed.

\section{Acknowledgements}

This work was supported by key projects of science and technology research of Hebei Province higher education institutions, China (ZD2018239) and independent research project of Yan Shan University Young teachers, China (14LGA015).

\section{References}

[1] Kashani, H., Amadeh, A., and Vatanara, M. R. 2008.
"Improvement of Wear Resistance of Hot Working Tool Steel by Hardfacing Part 2-Case Study." Materials Science and Technology 24 (3): 356-60.

[2] Chang, L. M., Lu, J. H., and Gou, H. Y. 2006. "Effect of Heat Treatment on the Microstructure and Hardness of C-Cr-W-Mo-V-RE Ferro-based Hardfacing Layer." China Welding 15 (1): 43-8.

[3] Scandella, F., and Scandella, R. 2004. "Development of Hardfacing Material in Fe-Cr-Nb-C System for Use under Highly Abrasive Conditions." Materials Science and Technology 20 (1): 93-105.

[4] Wang, X. H., Han, F., and Liu, X. M. 2008. "Effect of Molybdenum on the Microstructure and Wear Resistance of Ferro-based Hardfacing Coatings." Materials Science and Engineering $A 489$ (1-2): 193-200.

[5] Correa, O., Alcantara, N. G., and Tecco, D. G. 2007. "Development of an Iron-based Hardfacing Material Reinforced with Fe-(TiW)C Composite Powder." Metallurgical and Materials Transactions A: Physical Metallurgy and Materials Science 38 (5): 937-45.

[6] Yoo, J. W., Lee, S. H., and Yoon, C. S. 2006. "The Effect of Boron on the Wear Behavior of Iron-based Hardfacing Alloys for Nuclear Power Plants Valves." Journal of Nuclear Materials 352 (1-3): 90-6.

[7] Buchely, M. F., Gutierrez, J. C., and León, L. M. 2005. "The Effect of Microstructure on Abrasive Wear of Hardfacing Alloys." Wear 259 (1-6): 52-61.

[8] Dwivedi, D. K. 2004. "Microstructure and Abrasive Wear Behaviour of Iron Base Hardfacing." Materials Science and Technology 20 (10): 1326-30.

[9] Correa, E. O., Alcântara, N. G., and Tecco, D. G. 2007. "The Relationship between the Microstructure and Abrasive Resistance of a Hardfacing Alloy in the $\mathrm{Fe}-\mathrm{Cr}-\mathrm{C}-\mathrm{Nb}-\mathrm{V}$ System." Metallurgical and Materials Transactions A: Physical Metallurgy and Materials Science 38 (8): 1671-80.

[10] Lee, K. Y., Ko, K. H., and Kim, J. H. 2007. "Effects of Temperature and Sliding Distance on the Wear Behavior of Austenitic Fe-Cr-C-Si Hardfacing Alloy." Tribology Letters 26 (2): 131-5.

[11] Wang, X. M. 1999. Engineering Materials. Beijing: Mechanical Industry Press.

[12] Liu, Z. J., Ji, J., and Zhang, S. S. 1997. "Effect of Alloy Elements on Microstructure and Temperature-Wear-Resistibility of Plasma Arc Surfacing Layer." Transactions of the China Welding Institution 18 (4): 217-19. (in Chinese)

[13] Wu, C. J., Chen, G. L., and Qian, W. J. 2001. Metallic Materials. Beijing: Metallurgical Industry Press. 